\title{
PENGARUH DUKUNGAN SOSIAL TERHADAP MOTIVASI HIDUP ORANG DENGAN HIV ATAU AIDS (ODHA) DI PROVINSI KALIMANTAN TENGAH
}

\author{
${ }^{1}$ Nurul Chusna, Nurhalina \\ 1'Dosen Pengajar Fakultas IImu Kesehatan, \\ Universitas Muhammadiyah Palangkaraya
}

\begin{abstract}
Abstrak
Jumlah kumulatif HIV \& AIDS di Provinsi Kalimantan Tengah terus mengalami peningkatan dimana Pada Tahun 2017 dilaporkan terdapat 807 kasus. Berdasarkan hasil observasi situasi yang dihadapi penderita HIV \&AIDS sangat kompleks, selain harus menghadapi penyakitnya sendiri, mereka juga menghadapi stigma dan diskriminasi yang berdampak pada rendahnya motivasi hidup penderita. Sebagian besar pederita mengalami masalah pada fisik, psikis dan sosial sehingga diperlukan intervensi komprehensif (medikamentosa, nutrisi, dukungan sosial maupun psikoterapi/konseling. Tujuan penelitian ini adalah untuk mengetahui pengaruh dukunga sosial terhadap motivasi hidup ODHA di Provinsi Kalimantan Tengah. Jenis penelitian ini adalah observational study dengan penndekatan cross sectional study. Hasil penelitian yang dilakukan mengenai motivasi hidup dari partsipan didapat tema motivasi ekstrinsik dan motivasi intrinsik. Dukungan sosial yang diterima penderita HIV/A IDS. Partisipan memiliki pandangan yang sama bahwa mereka mendapatkan berbagai bentuk dukungan sosial. Dan berikut bentuk dukungan sosial yang peneliti peroleh dari hasil wawancara dengan partisipan yang dibentuk dalam tematema, yaitu dukungan fisik, dukungan emosional, dukungan keamanan, dukungan ketrampilan, dukungan sosial dan dukungan ekonomi. Sumber dukungan sosial yang didapat penderita HIV/A IDS dalam penelitian ini didapatkan tema sumber dukungan eksternal dan sumber dukungan internal. Dukungan sosial yang diharapkan penderita HIV/A IDS didapatkan empat tema. Tema tersebut adalah fasilitas untuk memenuhi kebutuhan ekonomi, fasilitas kesehatan, dukungan kesehatan dan pandangan masyarakat terhadap penderita HIV/AIDS positif.
\end{abstract}

Kata Kunci: Dukungan sosial, Motivasi Hidup, HIV \& AIDS 


\begin{abstract}
Abstrack
The cumulative number of HIV \& AIDS in Central Kalimantan Province continues to increase where in 2017 there were 807 reported cases. Based on observations of the situation faced by people with HIV \& AIDS is very complex, in addition to having to deal with their own disease, they also face stigma and discrimination that affects the low motivation of patients' lives. Most sufferers experience physical, psychological and social problems that require comprehensive interventions (medical, nutrition, social support and psychotherapy / counseling. The purpose of this study is to determine the effect of social support on the motivation of living ODHA in Central Kalimantan Province. This type of research is observational study with cross sectional study approaching. Results of research conducted on life motivation from participant obtained extrinsic motivation and intrinsic motivation themes Social support received by people with HIV / A IDS Participants have the same view that they get various forms of social support.And the following forms social support that researchers obtained from interviews with participants formed in the themes, namely physical support, emotional support, security support, skills support, social support and economic support Source of social support obtained by people with HIV / A IDS in In this study, the theme was obtained sources of external support and internal support sources. Four social themes are expected by HIV / A IDS sufferers. The theme is facilities to meet economic needs, health facilities, health support and community views of people with HIV / AIDS positive.
\end{abstract}

Keywords: Social support, Life Motivation, HIV \& AIDS

\title{
PENDAHULUAN
}

Pada Tahun 2017 jumlah kumulatif infeksi HIV di Indonesia mencapai 242.699. Sedangkan jumlah kumulatif AIDS dari Tahun 1987 sampai dengan maret 2017 mencapai 87. 453 orang. Jumlah AIDS terbanyak dilaporkan dari Jawa Timur (17.014), Papua (13.398), DKI Jakarta (8.769), Bali, Jawa Tengah (6.531) [1]

Penelitian yang dilakuakn oleh Refrensi [2] menunjukan bahwa isu stigma terhdap ODHA meliputi dilecehkan secara lisan, pemberian kode pada status pasien HIV, tempat pembuangan sampah yang dibedakan, pelayan kesehatan yang tidak memadai atau lambat, pelayanan yang berbeda, penggunaan Alat Pelindung Diri (APD) yang berlebihan, diidolasi serta melakukan tindakan medis tanpa melakukan informed consent.

Kajian lebih dalam mengenai faktorfaktor yang mempengaruhi rendahnya dukungan sosial terhadap kelompok OHDA perlu dilakukan. Persoalan stigma dan rendahnya dukungan sosial ditengarai sangat berkaitan dengan isu seksualitas, gender, kemiskinan termasuk juga ketakutan akan terinfeksi virus tersebut. Hasil penelitian Refrensi [3] menunjukan bahwa tingkat 
pengetahuan tentang HIV dan ketakutan irasional berhubungan signifikan terhadap rendahnya dukungan sosial kepada ODHA ( $p$ value $=0.04)$.

Menurut Refrensi [4] memperlihatkan hasil kajian bahwa Undang-Undang saja tidak cukup untuk mengatasi personal stigma diskriminasi karena Undang-Undang belum menyinggung persoalan HIV secara konprehensif. Di Kalimantan Tengah jumlah HIV \&AIDS terus mengalami peningkatan, hingga maret 2017 dilaporkan jumlah HIV \& AIDS mencapai 807 orang. Berdasarkan hasil observasi dukungan sosial terhadap ODHA di Kalimantan Tengah masih rendah dan kerapkali berdampak pada rendahnya motivasi hidup serta minimnya ODHA yang mengakses layanan kesehatan untuk pengobatan.

Berdasarkan uraian di atas peneliti tertarik untuk melakukan pengkajian terhadap pengaruh dukungan sosial terhadap motivasi hidup ODHA di Provinsi Kalimantan Tengah. Hasil penelitian diharapkan dapat memberikan informasi kepada instansi terkait untuk menghilangkan stigma dan meningkatkan dukungan sosial terhadap ODHA di Provinsi Kalimantan Tengah.

\section{METODE PENELITIAN}

Jenis penelitian ini adalah observational study dengan pendekatan cross sectional study .Partisipan dalam penelitian ini adalah ibu rumah tangga yang menderita HIV/AIDS yang berada Kalimantan tengah.

Penelitian ini meupakan jenis penelitian kualitatif dengan pendekatan phenomenological dengan cara pengumpul an data melalui wawancara mendalam (indepth interview) [5]. Metode kualitatif di gunakan untuk mendeskri psikan dukungan sosial terhadap motivasi hidup penderita HIV/AIDS. Rancangan penelitian ini adal ah penelitian kualitatif dengan pendekatan penelitian deskriptif fenomenologi yaitu strategi peneli tian yang berusaha memahami arti peristiwa dan kaitannya pada situasi tertentu dan fenomenologi merupakan penelitian tentang pengalaman [6]. menyatakan bahwa "makna" merupakan pengalaman pribadi yang dapat di bagikan atau disampaikan kepada orang lain secara obyektif dan dapat diambil intinya saja. Pengalaman merupakan suatu hal yang sifatnya sangat pri badi dari hal -hal psikis yang dirasakan, dipikirkan, yang pernah dialami berdasarkan kejadian atau peristiwa seseorang sehingga perlu pendekatan kualitatif untuk mengetahui.

\section{HASIL DAN PEMBAHASAN}

Partisipan dalam penelitian ini adalah penderita HIV/A IDS yang berjumlah dua puluh satu orang. Semua partisipan berdomisili di Kalimantan Tengah. Usia partisipan bervariasi, dengan usia termuda 23 tahun dan usia tertua 62 tahun. Partisipan disini berjenis kelamin laki-laki dan 
perempuan. Responden laki-laki tampak lebih feminim dan berpenampilan layaknya wanita (waria). Memiliki tingkat yang bervariasi muali dari lulusan SD, SLTP, SLTA, DIII dan S1. Status pekerjaan partisipan ada yang bekerja ada yang tidak bekerja.

Tabel 5.1 Karakteistik Responden Bedasarkan Jenis Kelamin

\begin{tabular}{lcc}
\hline Jenis Kelamin & Jumlah & Persentase \\
\hline Laki-laki & 4 & $19 \%$ \\
Perempuan & 17 & $81 \%$ \\
Total & 21 & $100 \%$ \\
& & \\
\hline
\end{tabular}

Tabel 5.2 Karakteistik Responden Bedasarkan Pekejaan

\begin{tabular}{lcc}
\hline \multicolumn{1}{c}{ Pekejaan } & Jumlah & Persentase \\
\hline Bekerja & 13 & $62 \%$ \\
Tidak Bekerja & 8 & $38 \%$ \\
Total & 21 & $100 \%$ \\
\hline
\end{tabular}

Tabel 5.3 Karakteistik Responden Bedasarkan Tingkat Pendidikan

\begin{tabular}{lcc}
\hline $\begin{array}{c}\text { Tingkat } \\
\text { Pendidikan }\end{array}$ & Jumlah & Persentase \\
\hline SD & 4 & $19 \%$ \\
SLTP & 6 & $28 \%$ \\
SLTA & 9 & $43 \%$
\end{tabular}

\begin{tabular}{lcc} 
DIII & 1 & $5 \%$ \\
S1 & 1 & $5 \%$ \\
Total & 21 & $100 \%$ \\
\hline
\end{tabular}

Tabel 5.4 Karakteistik Responden Bedasarkan Status Pernikahan

\begin{tabular}{lcc}
\hline \multicolumn{1}{c}{ Pekerjaan } & Jumlah & Persentase \\
\hline Belum Menikah & 2 & $10 \%$ \\
Menikah & 14 & $66 \%$ \\
Janda & 5 & $24 \%$ \\
Total & 21 & $100 \%$
\end{tabular}

\subsection{Analisis Tema}

Tabel 5.5 Analisis Tema Motivasi hidup

\begin{tabular}{ll}
\hline Tema 1: Motivasi & "yang kena banyak kok \\
Ekstrinsik & $\begin{array}{l}\text { jadi ya saya semangat } \\
\text { aja mbak" (P3) }\end{array}$ \\
Tema 2: Motivasi & "pokoknya saya berfikir \\
Intrinsik & positif” (P19)
\end{tabular}

Tema 3: "periksanya gratis, Dukungan fisik dikasih obat, pernah nginep dirumah sakit juga gratis " (P6)

$\begin{array}{ll}\text { Tema } 4: & \text { "Saling ngingetin minum } \\ \text { Dukungan } & \text { obat yang teratur" (P12) }\end{array}$ emosional 


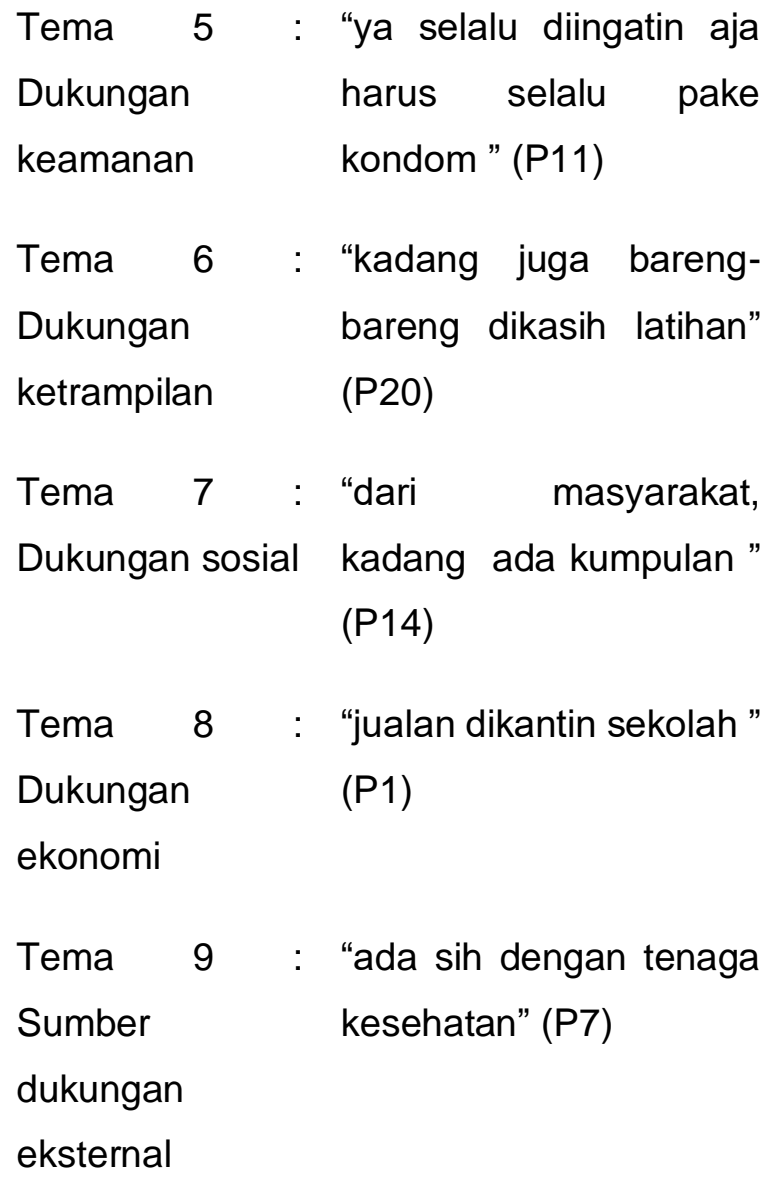

Tema 10 : "percaya diri aja " (P7)

Sumber

dukungan

internal

Tema 11 : “mengharapkan bantuan Fasilitas untuk pemerintah agar bisa memenuhi dibeikan usaha " (P21)

kebutuhan

ekonomi

Tema 12 : "tapi yang pasti obat Fasilitas jangan sampe putus kesehatan mbak" (P8)

\begin{tabular}{|c|c|}
\hline \multirow{2}{*}{$\begin{array}{l}\text { Tema } 13 \\
\text { Dukungan }\end{array}$} & "penting ada kawan yang \\
\hline & menyemangatin, ngasih \\
\hline kesehatan & $\begin{array}{l}\text { saran, tetap memberikan } \\
\text { didukung" (P16) }\end{array}$ \\
\hline Tema & masyarakat \\
\hline Pandangan & diharapkan \\
\hline masyarakat & tentang \\
\hline terhadap & masyarakat \\
\hline enderita & sampe kita dikucilkar \\
\hline V/AIDS positif & (P9) \\
\hline
\end{tabular}

\section{KESIMPULAN}

Dari penelitian yang dilakukan mengenai motivasi hidup dari partsipan didapat 2 tema yaitu motivasi ekstrinsik dan motivasi intrinsik. Dukungan sosial yang diterima penderita HIV/A IDS. Partisipan memiliki pandangan yang sama bahwa mereka mendapatkan berbagai bentuk dukungan sosial. Dan berikut bentuk dukungan sosial yang peneliti peroleh dari hasil wawancara dengan partisipan yang dibentuk dalam tema-tema, yaitu dukungan fisik, dukungan emosional, dukungan keamanan, dukungan ketrampilan, dukungan sosial dan dukungan ekonomi.

Sumber dukungan sosial yang didapat penderita HIV/A IDS dalam penelitian ini didapatkan dua tema yaitu sumber dukungan eksternal dan sumber dukungan internal. Dukungan sosial yang diharapkan penderita 
HIV/A IDS didapatkan empat tema. Tema tersebut adalah fasilitas untuk memenuhi kebutuhan ekonomi, fasilitas kesehatan, dukungan kesehatan dan pandangan masyarakat terhadap penderita HIV/AIDS positif.

\section{DAFTAR PUSTAKA}

1. Kementrian Kesehatan RI. 2017. Laporan Situasi Perkembangan HIV/AIDS dan PIMS di Indonesia Januari-Maret 2017. Ditjen P2P Kementrian Kesehatan RI. Jakarta.

2. Maharani Riri, 2014. Stigma dan Diskriminasi Orang Dengan HIV/ AIDS (ODHA) Pada Pelayanan Kesehatan dii Pekanbaru Tahun 2014. Jurnal Kesehatan Komunitas, Vol.2, Nomor 5 Nopember 2014.

3. Sofia Rizka. 2018. Stigma dan Diskriminasi Terhadap ODHA (Studi Pada Tenaga Kesehatan di Puskesmas Tanah Pasir Aceh Utara. Jurnal Kedokteran dan Kesehatan Malikul Saleh. Ojs.unimal.ac.id 4. Latifa, Ade \& Purwaningsih, Sri, Sunarti. 2011. Peran Masyarakat madani Dalam Mengurangi Stigma dan Diskriminasi Terhadap Penderita HIV \& AIDS. ejournal.kependudukan.lipi.go.id. Vol.VI No.2, 2011.

5. Poerwandari, K. 2005. Pendekatan Perilaku Untuk Penelitian Perilaku Manusia. UI, LPSP3. Jakarta
6. Smeet. 1994. Psikologi Kesehatan. Gramedia widiasarana Indonesia. Jakarta 